\title{
Nationalism in Europe: Trends and Cross-national Differences in Public Opinion
}

\author{
MARCEL COENDERS*, MARCEL LUBBERS** \& \\ PEER SCHEEPER $S^{\dagger}$ \\ *The Netherlands Institute for Social Research, PO Box 16164, 2500 BD the Hague, \\ the Netherlands. Email: m.coenders@scp.nl \\ **Netherlands Interdisciplinary Demographic Institute (NIDI), the Netherlands; \\ Department of Sociology, Radboud University Nijmegen, the Netherlands; and \\ Department of Sociology, University of Groningen, the Netherlands \\ †Department of Sociology, Radboud University Nijmegen, the Netherlands
}

In this contribution the focus is on nationalism, i.e. the view that one's own country and people are unique and superior, implying a negative comparison with regard to other national groups and countries. The research questions we set out to answer are: (1) what are the cross-national differences and trends in nationalism across Europe?

(2) Which individual and national characteristics can explain these differences and changes in nationalism in European countries? We use high-quality cross-national data from 20 countries from the 'National Identity' modules of the International Social Survey Programme, collected in 1995, 2003 and 2013. Considerable differences between countries were found; however, within countries the level of nationalism remained rather stable over the period from 1995 to 2013.

\section{Introduction}

The 'end of the nation' paradigm inspired by the work of Fukuyama (1989) has become outdated. Researchers have increasingly addressed the relevance of the nation over the last few decades (e.g. Norris 2005), culminating in the ' . . resurgence of nationalist discourse in the United States, mirroring long-term trends in the European public sphere. Politicians ... articulated visions of their nations under siege...' (Bonokowski 2016, 428). These long-term trends have been fed by predominantly but certainly not only - political leaders of the so-called radical right. Ó Maoláin (1987, viii) already noted that leaders of these movements propose a strong commitment ' ... to nationalism, to the point of xenophobia and ... a strong 
belief in the inherent supremacy of the white race, coupled with opposition to immigration of, or interbreeding with other races ...'. Mudde (2007, 16-17) emphasised that nationalism is actually at the core of radical right ideologies, ' ... declaring that the maintenance and strengthening of one's own nation is the highest principle of human thought and action and denigrates other nations...', which is still considered crucial in recent studies (Liang 2016, Lubbers and Coenders 2017). The rise of the European radical right parties is also proposed to be at least partially explained by increasing favourable attitudes towards the own nation (Mudde 2007). Empirical evidence for the latter is, however, scarce, although research shows some evidence that national identification and national pride predict radical right support (Lubbers and Coenders 2017). More recently, latent versions of nationalism have come to the surface via numerous websites of social movements related to the alternative right (https://alternative-right.blogspot. com/), focusing on (white) nationalism, but also suspected of covering up racism and white supremacism (https://blog.ap.org/behind-the-news/writing-about-the-alt-right).

In the research tradition on favourable stances towards one's own nation, it is emphasised that one should conceptually differentiate between different dimensions of national attachments. In particular, many researchers have drawn a clear distinction between 'patriotism', indicating positive feelings and a sense of pride in one's country versus 'nationalism', referring to feelings of national superiority and dominance (Coenders et al. 2004; Grimm et al. 2016). Nationalism is described as the view that one's own country and people are unique and superior. It implies a negative comparison of other national groups and countries (Kosterman and Feshbach 1989). These feelings of superiority are intertwined with a blind, uncritical attachment to one's own national group and country. Patriotism, on the other hand, refers to feelings of pride in one's people and country and - in contrast to nationalism - reflects a critical understanding rather than a blind attachment to the national group and the country.

In previous survey research, nationalism was found to be rather strongly related to exclusionist reactions towards immigrants and refugees (Coenders et al. 2004). Since these phenomena - nationalism and exclusionism - have been shown to be so strongly related, we also use theories that address both nationalism, i.e. in-group favouritism, versus ethnic exclusionism, i.e. out-group antagonism 'in conjunction': this holds particularly for social identity theory and ethnic competition theory (Scheepers et al. 2002).

In this contribution, we will, therefore, focus on nationalism and set out to fill recently acknowledged lacunae (Bonokowski 2016, 440). First, we will describe systematically variations in nationalism within nations and changes over time: although this has been done for the period of $1995 / 1996$ to $2003 / 2004$, we will consider more recent times, i.e. 2012/2013. Second, we analyse how differences in nationalism among European citizens can be explained, examining contextual factors so far ignored in previous research (Bonokowski 2016). Third, we will address so-called 'sub-group' differences, not only for one point in time (Smith and Kim 2006), but for a lengthy research period, 1995/1996-2012/2013. Fourth, in order to address the second and third lacunae, we will propose an overarching theoretical framework from which we systematically derive sets of hypotheses to be tested (Bonokowski 2016). 
Taking advantage of cross-national comparative surveys from the International Social Survey Programme (ISPP), we investigate the differences in nationalism among the general public in 20 European countries as well as differences between social categories within these countries over nearly two decades. The research questions we set out to answer are: (1) what are the cross-national differences and trends in nationalism across Europe? (2) Which individual and national characteristics can explain these differences and changes in nationalism in European countries?

\section{Theories and Hypotheses}

In order to understand differences within and between countries as well as trends over time and, moreover, between social categories within countries, we propose a theoretical framework, focusing both on micro and macro level determinants. We will use multidisciplinary theoretical insights that focus in conjunction on nationalism and exclusionism, i.e. ethnic competition theory and framing theory.

\section{Ethnic Competition Theory}

We build on classics in realistic conflict theories, proposing that within each social system, there are social groups, such as ethnic groups, that compete for material goods and resources (power, status, privileges and other scarce resources) or adhere to conflicting values (Coser 1956). Whenever there are conflicts of interest between ethnic groups, these groups become mutual competitors, driving perceptions of outgroup threat which may only partly reflect actual intergroup competition (Blalock 1967), intergroup competition on the labour market for jobs or on the housing market for houses. Actual intergroup competition and perceived ethnic threat can be expected to affect the processes of social identification and social contraidentification, insights derived from social identity theory (Tajfel 1981): the first process drives in-group favouritism, i.e. nationalism, whereas the latter drives out-group exclusionism, i.e. out-group antagonism.

The synthesis of both theoretical strands is labelled ethnic competition theory, proposing that nationalism as well as exclusionism are driven by social identity needs, while the intensity of nationalism and exclusionism varies situationally, depending on the amount of actual competition and/or perceived threat. The general proposition of ethnic competition theory, therefore, reads:

the stronger the actual competition between ethnic groups at an individual or contextual level and/or the stronger perceptions of ethnic threat, the more the mechanisms of social (contra-) identification will be reinforced, inducing stronger nationalism and exclusionism. (Scheepers et al. 2002)

Ethnic competition theory is a multi-level theory, which can be applied to deduce micro- as well as macro-hypotheses regarding the variations, within and between countries, in nationalism. 
According to ethnic competition theory, cross-national variations in nationalism are related to cross-national differences in the level of actual or perceived competition. At this contextual level, we expect that (actual or perceived) competition may be related to conditions where there are (1) increasing numbers of people from different ethnic groups competing for approximately the same amount of scarce resources, or (2) stable numbers of people from different ethnic groups competing for a decreasing amount of scarce resources. The actual level of ethnic competition in a country may depend on demographic conditions and economic conditions (cf. Blalock 1967). With respect to demographic conditions, ethnic diversity (i.e. stable or increasing numbers of people from different ethnic groups) may induce stronger competition and threat among the dominant ethnic majority group. Regarding economic conditions, less economic affluence or higher unemployment levels create a situation in which, ceteris paribus, (stable or increasing numbers of) people compete for fewer scarce resources.

Although there is much research on the relation between macro-economic conditions and anti-immigrant attitudes (Billiet et al. 2014, Semyonov et al. 2006), these theoretical notions have been only rarely been tested regarding nationalism (with the exception of Coenders et al. 2004). Following Olzak (1992), we argue that a constant high level of competition may not affect nationalism that strongly, but if demographic and economic conditions suddenly deteriorate, people may become more nationalistic, just as they are more likely to become more antagonistic. People might be overwhelmed by these sudden changes, because there was little time to absorb the changes (Olzak 1992).

Many European countries have experienced strong changes in terms of demographic and economic conditions. Hence, Europe has become a natural arena to propose and test such insights. We expect that nationalism will be more strongly prevalent in countries with high levels of ethnic diversity, i.e. with larger migrant populations, and with poor economic conditions, as indicated by high unemployment levels. Regarding changes over time, we expect that nationalism will increase in countries with an increasing size of the migrant population and increasing levels of unemployment.

At the individual level, members of the ethnic majority group may differ in the extent to which they view migrants as a threat because the level of actual competition may vary between social categories of the ethnic majority population. Typically, migrants have a relatively disadvantaged socio-economic position compared with the ethnic majority population in many European countries. A relatively large proportion of immigrants is located in the lower strata of the host society, characterised by relatively low educational attainment, low income, a high proportion of manual labour, as well as higher levels of unemployment (Süssmuth 2007).

Presumably, social categories within the ethnic majority which hold similar socioeconomic positions to those of migrants will have to compete more strongly with immigrants, on for instance, the labour market, than other members of their majority group and therefore may, particularly, perceive higher levels of ethnic competition, and consequently, display stronger nationalism (Scheepers et al. 2002). Hence, we 
expect that nationalism will be more strongly prevalent among ethnic majority individuals with a relatively low educational level, among the unemployed persons, as well as among those with a relatively low income level.

\section{Mediator: Perceived Ethnic Threat}

Blalock (1967) divided the concept of intergroup competition into two components: actual competition and perceived competition. Likewise, the distinction between actual and perceived threat is often recognised in theoretical terms (Quillian 1995) and has received much empirical attention (e.g. Scheepers et al. 2002). We will explicitly test the effects of the perception of ethnic threat on nationalism, which has not been done before. The hypothesis therefore reads: the perception of ethnic threat is positively related to nationalism.

\section{Framing Theory}

A complementary approach to ethnic competition theory to understand societal conditions of nationalism focuses on the role of political entrepreneurs who affect the political discourse in a country, as is proposed by framing theory (Slothuus and De Vreese 2010). A changing supply of political parties who air, and campaign upon, specific messages may affect how people perceive these issues (Slothuus and De Vreese 2010). Previously, Semyonov et al. (2006) indeed showed that support for the radical right influences support for anti-migrant attitudes. The radical right party family defines itself also in nationalist terms. It stresses, on the one hand, the uniqueness and superiority of the nation and, on the other hand, the threats against which the nation should be protected (Mudde 2007). In countries in which those parties have gained more popular support and have been better represented, a stronger nationalist discourse can be anticipated - not only in parliament but also in newspapers and other media to which the population has been exposed. Hence, we expect nationalism to be more strongly prevalent in countries with, ceteris paribus, a larger share of votes for radical right-wing political parties. Furthermore, we expect that nationalism has increased in countries with increasing shares of votes for radical right-wing political parties.

\section{Methods}

\section{Data and Measurement}

Data were derived from the 1995, 2003 and 2013 'National Identity' modules of the International Social Survey Programme (ISSP). We included all European countries that participated in at least two of the three repeated 'National Identity' modules. This led to a total of 53 national surveys (Table 1).

To operationalise 'nationalism', we build upon previous studies that examined the cross-national equivalence of the ISSP measurements (Coenders, et al. 2004; Davidov 2009). We operationalised 'nationalism' by three items, each measured with 
Table 1. Mean score on nationalism across 20 European countries and changes over time.

\begin{tabular}{|c|c|c|c|c|c|c|}
\hline Country & 1995 & 2003 & 2013 & $\begin{array}{c}\text { Change } \\
1995-2003\end{array}$ & $\begin{array}{c}\text { Change } \\
2003-2013\end{array}$ & $\begin{array}{c}\text { Overall change } \\
1995-2013\end{array}$ \\
\hline Norway & 3.24 & 3.00 & 3.12 & - & + & - \\
\hline Sweden & 3.10 & 2.96 & & - & & \\
\hline Finland & & 3.20 & 3.19 & & 0 & \\
\hline Denmark & & 3.43 & 3.46 & & 0 & \\
\hline Great Britain & 3.27 & 3.26 & 3.30 & 0 & 0 & 0 \\
\hline Ireland & 3.39 & 3.24 & 3.03 & - & - & - \\
\hline Netherlands & 2.77 & 2.79 & & 0 & & \\
\hline Germany (West) & 2.80 & 2.87 & 3.06 & 0 & + & + \\
\hline Germany (East) & 2.98 & 2.86 & 2.99 & 0 & 0 & 0 \\
\hline France & & 2.93 & 3.08 & & - & \\
\hline Austria & 3.67 & 3.49 & & - & & \\
\hline Switzerland & & 3.17 & 3.43 & & + & \\
\hline Spain & 3.32 & 3.38 & 3.20 & 0 & - & - \\
\hline Portugal & & 3.55 & 3.32 & & - & \\
\hline Poland & 3.62 & 3.43 & & - & & \\
\hline Czech Republic & 3.19 & 3.32 & 3.38 & + & 0 & + \\
\hline Slovakia & 3.06 & 3.07 & 3.38 & 0 & + & + \\
\hline Hungary & 3.62 & 3.71 & 3.52 & + & - & - \\
\hline Slovenia & 3.44 & 3.34 & 3.08 & - & - & - \\
\hline Bulgaria & 3.78 & 3.56 & & - & & \\
\hline Latvia & 3.23 & 2.87 & 3.02 & - & + & - \\
\hline Overall mean & 3.26 & 3.22 & 3.23 & - & + & - \\
\hline
\end{tabular}

Note: + significant increase, - significant decrease; 0 no significant change. $p<0.05$ two-tailed.

Source: International Social Survey Programme 1995, 2003, 2013, own calculations.

a 5-point agree-disagree answer scale. The item formulations read: 'I would rather be a citizen of [country] than of any other country in the world', 'The world would be a better place if people from other countries were more like the [country nationality]', and 'People should support their country even if the country is in the wrong'. The first two items refer to the perceived superiority of one's own nation. The third item refers to a blind, absolute and uncritical attachment to one's own country, reflecting blind patriotism (Schatz et al. 1999), which we consider an inherent component of nationalism.

Overall, across all countries and years, Cronbach's alpha was 0.57 . This moderate reliability is not surprising given the limited number of items. The reliability was rather stable over time: 0.56 in 1995 and 2003, and 0.58 in 2013. Across countries and specific years, the reliability ranged from 0.42 (Hungary, 2003) to 0.68 (Spain, 2013).

'Perceptions of migrant threat' were measured by four items. The 5-point agreedisagree items read 'immigrants increase crime rates', 'immigrants are generally good for [country's] economy', 'immigrants take jobs away from people who were born in [country]', and 'immigrants improve [country's nationality] society by bringing new ideas and cultures'. The first and third item were both reversed so that high scores 


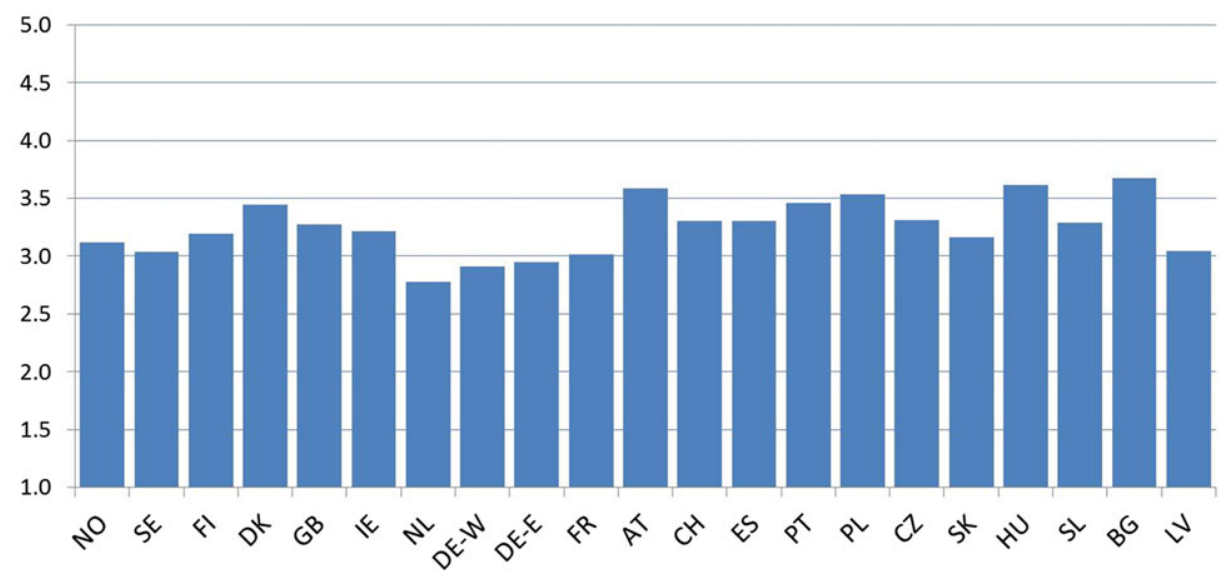

Figure 1. Cross-national differences in nationalism: Averages across three ISSP surveys in 1995, 2003 and 2013.

refer to stronger perceptions of threat. Together, the items refer to perceptions of economic, cultural and safety threat. The overall reliability was satisfactory: Cronbach's alpha was 0.70 . Over time, the reliability of this measurement increased slightly, from 0.67 in 1995, 0.71 in 2003, to 0.73 in 2013. 'Local orientation' was measured by a single item: 'how close do you feel to your town or city?' with four answer categories ranging from very close to not close at all (reversed coding).

\section{Contextual Variables}

Figures from the UN were applied to indicate the 'migrant stock', i.e. the share of international migrants as a percentage of the total population (United Nations, 2009). Figures for the unemployment rate were derived from the World Bank (2016), which provided the unemployment rate as a percentage of the total labour force, based on modelled ILO estimates. We applied the figures for the year of survey measurement. Finally, to measure the share of votes for radical right-wing political parties, we applied the general election results that were held in the year of the survey or in the most recent preceding year. We classified radical right-wing political parties according to the standards in the literature (Mudde 2007).

\section{Results}

\section{Descriptive Findings}

The average score on nationalism across all countries and years was 3.23. Hence, on a scale from 1 to 5, on average, European citizens tend to slightly agree with the items indicating feelings of national superiority. The average scores per country across the years of measurement are displayed in Figure 1. As displayed in Figure 1, the Dutch 
were the least nationalistic (2.78), followed by Germans (2.91 in the Western part and 2.95 in the Eastern part of Germany).

When we look at the overall change in nationalism in Europe between 1995 and 2013 , it seems as if there is hardly any substantial change. Table 1 displays the mean score on nationalism in each country for all available years. On the right-hand side of the table, we indicate for each country whether there was a significant increase or decrease in nationalism.

As displayed in Table 1, we observed different trends across countries. Despite the considerable differences in the within-country changes, there appeared to be an overall trend towards convergence as the differences between countries in 2013 were smaller than in 1995. In countries with a high level of nationalism in the mid 1990s there tends to be a pattern towards lower levels of nationalism in later years, whereas other countries with low levels of nationalism in the mid 1990s tend to show an increase in nationalism over time. However, we note that the changes in nationalism within countries across a period of almost two decades were considerably smaller than the differences between countries in the average level of nationalism.

We applied multi-level analyses to take the nested structure of our data -individuals, year of data collection and country - into account. Individuals participated in surveys that were administered in a specific country and year, i.e. a specific country-year combination. As it is important to include random effects for each relevant level of analysis (cf. Schmidt-Catran and Fairbrother 2016), we applied a three-level model of individuals (level 1), surveys, i.e. country-year combinations (level 2), and countries (level 3). As mentioned and displayed in Table 1, there were 53 different country-year combinations, which were in turn nested within 21 'nations'. The country-level as the highest level of analysis takes into account that respondents from the same country are more similar than respondents from different countries.

To assess the effects of national characteristics on nationalism between countries and over time, we included the contextual variables both as 'within' and 'between' components (Te Grotenhuis et al. 2015). The 'between' contextual variable was equal to the average score of the national characteristics across time points. The 'within' contextual variable was constructed as the national characteristic at time $t$, minus the average score across time points, hence indicating changes in social contexts within particular countries.

\section{Results of Multilevel Analyses}

Table 2 presents the results of our multilevel analyses. There was much less variance at the country and country-year level. Yet, these variance components also indicate that differences within countries were smaller than differences between countries.

In model 1, we included contextual variables both as within and between components. We found that the migrant stock in a country was negatively related to nationalism. Hence, nationalism was less widespread in countries with a larger migrant population. We found no effect of the level of unemployment. We did, 
Table 2. Unstandardized multilevel regression estimates of nationalism, 20 countries, 1995, 2003, 2013.

\begin{tabular}{|c|c|c|c|c|}
\hline & model 0 & model 1 & model 2 & model 3 \\
\hline \multicolumn{5}{|l|}{ Contextual characteristics } \\
\hline Migrant stock (BE) & & $-0.024^{*}$ & $-0.024 * *$ & $-0.017^{*}$ \\
\hline Unemployment (BE) & & 0.017 & 0.008 & 0.010 \\
\hline Radical right (BE) & & $0.020^{*}$ & $0.017^{*}$ & $0.017^{*}$ \\
\hline Migrant stock (WI) & & -0.010 & -0.004 & -0.009 \\
\hline Unemployment (WI) & & 0.003 & 0.002 & 0.002 \\
\hline Radical right (WI) & & -0.003 & -0.000 & 0.002 \\
\hline \multicolumn{5}{|l|}{ Individual characteristics } \\
\hline Age & & & $0.006^{* * *}$ & $0.005 * * *$ \\
\hline Male & & & $0.043^{* * *}$ & $0.027 * * *$ \\
\hline Education & & & $-0.040 * * *$ & $-0.025^{* * *}$ \\
\hline \multicolumn{5}{|l|}{ Denomination (ref $=$ none $)$} \\
\hline Catholic & & & $0.188 * * *$ & $0.136 * * *$ \\
\hline Protestant & & & $0.159 * * *$ & $0.118^{* * *}$ \\
\hline other Christian & & & 0.030 & 0.045 \\
\hline not Christian & & & $-0.081 *$ & -0.018 \\
\hline \multicolumn{5}{|c|}{ Church attendance (ref. $=$ never) } \\
\hline once a week or more & & & $0.068 * * *$ & $0.059 * * *$ \\
\hline once a month or more & & & $0.048 * * *$ & $0.042 * *$ \\
\hline less & & & $0.035^{* * *}$ & $0.027 * *$ \\
\hline \multicolumn{5}{|l|}{ Income (ref. $=$ highest) } \\
\hline lowest income & & & $0.086^{* * *}$ & $0.058 * * *$ \\
\hline less than average income & & & $0.053^{* * *}$ & $0.031 * *$ \\
\hline more than average income & & & 0.020 & 0.013 \\
\hline income missing & & & $0.060 * * *$ & $0.025^{*}$ \\
\hline \multicolumn{5}{|c|}{ Social position (ref. = paid work) } \\
\hline unemployed & & & -0.020 & -0.019 \\
\hline student & & & $-0.057 * * *$ & -0.026 \\
\hline domestic work & & & $0.048 * *$ & $0.047 * *$ \\
\hline sick or disabled & & & $0.085^{* * *}$ & $0.055^{*}$ \\
\hline retired & & & $0.103^{* * *}$ & $0.084 * * *$ \\
\hline Other & & & $0.005^{* * *}$ & 0.008 \\
\hline Perceived immigrant threat & & & & $0.250 * * *$ \\
\hline Local orientation & & & & $0.155^{* * *}$ \\
\hline \multicolumn{5}{|l|}{ Variance } \\
\hline Country & $0.045^{* *}$ & $0.027 *$ & $0.019^{*}$ & $0.016^{*}$ \\
\hline Country-year & $0.016^{* * *}$ & $0.015^{* * *}$ & $0.013^{* * *}$ & $0.013^{* * *}$ \\
\hline Individual & $0.639 * * *$ & $0.639 * * *$ & $0.568 * * *$ & $0.515^{* * *}$ \\
\hline
\end{tabular}

Note: $\mathrm{BE}=$ between component, $\mathrm{WI}=$ within component. $* * *=p<0.001 ; * *=p<0.010$, $*=p<0.05$, two-tailed. Source: International Social Survey Programme 1995, 2003, 2013, own calculations.

however, find that nationalism was stronger in countries with a stronger presence of radical right parties.

Moreover, we found that the within-country changes over time in the level of nationalism were overall not related to over time changes in the size of the migrant population, the unemployment level or the share of the radical right parties. 
Hence, although nationalism is stronger in countries with a larger share of radical right parties, an increase in the popular vote for the radical right was - overall not related to an increase in nationalism. Neither the change in migrant population nor unemployment level were related to within-country changes in nationalism.

In model 2 we added the individual background variables. We found that nationalism was negatively related to the educational level: lower educated respondents were more nationalistic. Furthermore, lower income groups were more nationalistic than the highest income group. Next, the findings showed that nationalism was higher among the elderly, those who consider themselves members of a religious denomination and those who frequently visited church. Regarding religious denomination, we found that Catholics and Protestants showed more nationalism, whereas those belonging to non-Christian denominations showed less nationalism.

Finally, we added the attitudinal variables - perceived migrant threat and local orientation. Both were significantly related to nationalism: nationalism was stronger among citizens who felt threatened by immigrants and when people have a stronger local orientation. Perceived ethnic threat turned out to be the most important determinant of nationalism.

\section{Conclusions and Discussion}

In this study, we analysed nationalism among citizens in 20 European countries between 1995 and 2013 and we examined its individual and societal conditions. We found that, on average, nationalism was not very widespread in Europe, but considerable differences in levels of nationalism between countries do exist.

Regarding changes in nationalism across nearly two decades, the overall level of nationalism in Europe remained rather stable between 1995 and 2013, in spite of the fact that, over the past decades, European countries have witnessed significant demographic, economic and political changes. Country-specific trends in nationalism are, on average (across all countries), not related to changes in the size of the migrant population, unemployment nor the share of the radical right. Hence, our analyses show no support for generic explanations for changing nationalism among European citizens. That the average nationalistic opinion changed so little over 20 years of demographic, economic and political turmoil brings us to the conclusion that nationalist attitudes are formed within a country context, possibly during formative years, and do not alter that quickly.

Regarding the role of societal factors as explanations for nationalism, we found no support for ethnic competition theory: neither ethnic diversity nor unemployment is associated with levels of nationalism, not from a cross-national perspective and not from a longitudinal perspective. These findings are clearly at odds with this theory and previous research which found support for the association between these competitive, national circumstances on the one hand and exclusionist reactions and threat towards migrants on the other hand (e.g. Coenders et al. 2013). Here we found 
an opposite association with ethnic diversity, namely that nationalism was less widespread in countries with higher shares of migrants. Contact theory may play a role here, as a larger share of migrants in a country creates more opportunities for interethnic contact (Hewstone 2015). Indeed, previous research found very consistent relationships between migrant stock and interethnic contacts (Savelkoul et al. 2011).

In line with framing theory, we found more nationalism in countries with more support for radical right parties. Radical right parties emphasise the uniqueness of the national culture and glorify the national past. The more such nationalistic frames dominate the political discourse, the more citizens are exposed to these views. However, also here, no support was found for the role of changes over time, in line with findings from Bohman and Hjerm (2016) on anti-immigration attitudes. The non-findings in these studies might be due to the relatively unstable success of radical right parties with the exceptions, however, of Poland, Hungary and, moreover, Austria. It may also be due to other parties that take on board stances voiced by the radical right. Instead of success for radical right parties, the voicing of nationalism and anti-migration sentiment within the political arena may contribute to the understanding of changes in nationalism.

Coinciding with ethnic competition theory, we found more nationalism among lower income groups and those who perceive threat, but not among the unemployed. We also found more nationalism among elderly, Christian denominations, frequent churchgoers and among those with a stronger local orientation. Both perceived ethnic threat and localism are strongly associated with nationalism. Our contribution also provides evidence for the strong cleavage between lower and higher educated with the former being more locally oriented and having stronger perceptions of ethnic threat than the latter. Consequently, nationalism is particularly more widespread among the lower educated.

Overall, we find over time stability of nationalism within countries, in spite of changes in the demographic compositions of these countries. Considering the absence of significant changes in nationalism, theories on societal changes which aim to explain such changes, are actually still somewhat redundant. Theories to explain differences in levels of nationalism between countries are, however, more on target. There may be two contradictory mechanisms at work, related to the level of migrant stock in these countries. In countries with larger shares of migrants, on the one hand, part of the (probably privileged) citizenry may have had opportunities for interethnic contacts, reducing interethnic cleavages in their societies. On the other hand, part of the (probably deprived) citizenry may perceive these migrants as a threat, which may also be the picture that radical right parties spread, inducing interethnic cleavages in these societies. This social tension that permeates through societies is bound to create even stronger cleavages, not only between majority and minority groups, but also within majority groups - and also between privileged and deprived segments within majority groups. 


\section{References}

Billiet J, Meuleman B and De Witte H (2014) The relationship between ethnic threat and economic insecurity in times of economic crises: analysis of European Social Survey data. Migration Studies 2(2), 135-161.

Blalock H (1967) Toward a Theory of Minority-group Relations. New York: John Wiley \& Sons.

Bohman A and Hjerm M (2016) In the wake of radical right electoral success: a crosscountry comparative study of anti-immigration attitudes over time. Journal of Ethnic and Migration Studies 42(11), 1729-1747.

Bonokowski B (2016) Nationalism in settled times. Annual Review of Sociology 42, 427-449.

Coenders M, Gijsberts $\mathbf{M}$ and Scheepers P (2004) Chauvinism and patriotism in 22 countries. In Gijsberts M, Hagendoorn L and Scheepers P (eds), Nationalism and Exclusion of Migrants: Cross-National Comparisons. Aldershot: Ashgate, pp. 26-69.

Coenders M, Lubbers $\mathbf{M}$ and Scheepers P (2013) Resistance to immigrants and asylum seekers in the European Union: cross-national comparisons of public opinion. In Freeman G, Hansen R and Leal D (2013) Immigration and Public Opinion in Liberal Democracies. New York: Routledge, pp. 21-50.

Coser L (1956) The Functions of Social Conflict. Glencoe, IL: Free Press.

Davidov E (2009) Measurement equivalence of nationalism and constructive patriotism in the ISSP: 34 countries in a comparative perspective. Political Analysis 17(1), 64-82.

Fukuyama F (1989) The end of history? The National Interest 16, 3-18.

Grimm J, Huddy L, Schmidt P and Seethaler J (2016) Dynamics of National Identity. Media and Societal Factors of What We Are. London: Routledge.

Hewstone M (2015) Consequences of diversity for social cohesion and prejudice: the missing dimension of intergroup contact. Journal of Social Issues 71(2), 417-438.

Kosterman R and Feshbach S (1989) Toward a measure of patriotic and nationalistic attitudes. Political Psychology 10, 257-274.

Liang C (2016) Europe for the Europeans, the Foreign and Security Policies of the Populist Radical Right. Oxon: Routledge.

Lubbers M and Coenders M (2017) Nationalistic attitudes and voting for the radical right in Europe. European Union Politics 18(1), 98-118.

Mudde C (2007) Populist Radical Right Parties. Cambridge: Cambridge University Press.

Norris P (2005) Radical Right: Voters and Parties in the Electoral Market. Cambridge: Cambridge University Press.

Ó Maolain C (1987) The Radical Right, a World Directory. London: Longman.

Olzak S (1992) The Dynamics of Ethnic Competition and Conflict. Stanford, CA: Stanford University Press.

Quillian L (1995) Prejudice as a response to perceived group threat: population composition and anti-immigrant and racial prejudice in Europe. American Sociological Review 60, 586-611.

Savelkoul M, Gesthuizen M and Scheepers P (2011) Explaining relationships between ethnic diversity and informal social capital across European countries and regions: tests of constrict, conflict and contact theory. Social Science Research 40, 1091-1107.

Schatz R, Staub E and Lavine H (1999) On the varieties of national attachment: blind versus constructive patriotism. Political Psychology 20(1), 151-174. 
Scheepers P, Gijsberts M and Coenders M (2002) Ethnic exclusionism in European countries: public opposition to civil rights for legal migrants as a response to perceived ethnic threat. European Sociological Review 18, 17-34.

Schmidt-Catran A and Fairbrother M (2016) The random effects in multilevel models: getting them wrong and getting them right. European Sociological Review 32(1), 23-38.

Semyonov M, Raijman R and Gorodzeisky A (2006) The rise of anti-foreigner sentiment in European societies, 1988-2000. American Sociological Review 71(3), 426-449.

Slothuus R and De Vreese C (2010) Political parties, motivated reasoning, and issue framing effects. The Journal of Politics 72(3), 630-645.

Smith TW and Kim S (2006) National pride in comparative perspective: 1995/96 and 2003/04. International Journal of Public Opinion Research 18(1), 127-136.

Süssmuth R (2007) Ethnic Minorities in the Labour Market. Report of the High Level Advisory Group of Experts on the social integration of ethnic minorities and their full participation in the labour market. Brussels, European Union.

Tajfel H (1981) Human Groups and Social Categories. Studies in Social Psychology. Cambridge: Cambridge University Press.

Te Grotenhuis M, Scholte M, De Graaf N and Pelzer B (2015) The between and within effects of social security on church attendance in Europe 1980-1998: the danger of testing hypotheses cross-nationally. European Sociological Review 31(5), 643-646.

United Nations, Department of Economic and Social Affairs, Population Division (2009) Trends in International Migrant Stock. United Nations database.

World Bank (2016). Database. World Development Indicators. www.worldbank.org.

\section{About the Authors}

Marcel Coenders is a scientific strategist on inclusion and exclusion at the Netherlands Institute for Social Research, the Hague, the Netherlands. Previously, he was an associate professor at the Department of General Social Sciences at the University of Utrecht.

Marcel Lubbers is senior researcher at the Netherlands Interdisciplinary Demographic Institute/KNAW as well as professor of inclusion and exclusion of immigrants at the Department of Sociology at Radboud University and the Department of Sociology at the University of Groningen.

Peer Scheepers is a professor of comparative research methodology at the Department of Sociology at Radboud University. He is an elected member of the Royal Dutch Academy of Arts and Sciences and of Academia Europeae. 